\title{
Closure of uranium tailings facilities: environmental considerations, regulatory framework and conceptual options
}

M.R. Gunsinger Golder Associates Ltd., Canada

B. Andruchow Golder Associates Ltd., Canada

E. Becker Golder Associates Ltd., Canada

\begin{abstract}
Uranium tailings are the residues that remain after uranium has been extracted and concentrated from ore materials. By virtue of the ore-rock mineralogy, and the beneficiation and concentration processes, the extraction of uranium from the ore material is not completely efficient, resulting in concentrations of uranium in the tailings that often exceed the background concentrations in the surrounding native materials. In addition, the other radionuclides in uranium-238 decay chain are of no commercial use and are shunted to the tailings circuit. Depending on solubility characteristics, the residual radionuclides in the tailings can become mobilised, potentially degrading the quality of nearby surface water and groundwater to levels deemed unacceptable by local regulations. In addition, the presence of uranium-decay series radionuclides constitutes a source of ionising radiation and gaseous radon, which can result in the exposure of receptors to radiation doses greater than regulatory limits. As such, uranium tailings represent highvolume, low-level radioactive wastes that require special management and closure considerations.

Before evaluating potential closure or rehabilitation strategies for tailings management facilities, the technical aspects and the risks associated with the tailings need to be well understood. In regard to the environmental risks associated with uranium tailings, the potential sources, pathways and receptors of radiation and radioactive substances require special consideration. Local governing policies, acts and regulations need to be considered, which will provide the regulatory framework and in some cases the criteria with which the closure activities need to comply. In the case of low-level radioactive waste, such as uranium tailings, particular consideration needs to be given to relevant radiation protection standards and guidelines. Along with the local regulation, the characteristics of the source-term, receptor exposure pathways and related human and ecological health risks will largely govern the appropriate mitigation strategies.
\end{abstract}

Closure strategies for uranium tailings may include the implementation of a combination of engineeredcontrol measures to reduce the contaminate source, immobilise or isolate contaminates within a defined area or reduce the flux of contaminates through a specific-exposure pathway. In many cases, the selected closure option for uraniferous tailings will need to include a combination of strategies to mitigate impacts due to radionuclide leaching, emanation of ionising radiation and release of radon gas. This paper provides an overview of the environmental considerations, regulatory framework and conceptual options for the closure of uranium tailings facilities.

\section{Introduction}

Tailings generated from uranium ore beneficiation represent low-level radioactive wastes due to the presence of the residual uranium and the other radioisotopes present within the uranium ore. Generally speaking, only a minor percentage of the original radioactivity present in the ore material is captured within the uranium concentrate, and the majority of the radioactivity is retained in the tailings (Bryan and Siegel, 2004). Tailings produced from the milling and concentration of other ore types can also be a source of lowlevel radiation if radioactive elements, such as uranium, thorium and radium, are present within the ore zone at sufficiently high concentrations. The radioactive nature of uranium tailings, or tailings containing 
elevated concentrations of radionuclides, results in the need to expand the understanding of potential environmental issues from those most commonly encountered at mine sites.

Special considerations that are related to potential environmental and human health impacts of uranium tailings include the following:

- Leaching of radionuclides (i.e., uranium and daughter products) through surface runoff or subsurface pathways into the downgradient groundwater and surface water environments.

- Emanation of ionising radiation, in particular from tailings that have been transported from the storage facility into the receiving environment through erosion and wind dispersion.

- Emission of radon gas that is transported through dispersion mechanisms to inhabited areas.

The potential sources, pathways and receptors of radionuclides (including radon gas) and ionising radiation, and the associated risks, should be well understood before initiating the process of developing closure strategies. Implementing a closure plan prior to understanding the key environmental issues, including those that are radionuclide- and radiation-specific, creates risk to the project. The characteristics of the source term and receptor exposure pathways, in addition to local regulations, will largely govern the appropriate mitigation strategies. Based on the understanding of the environmental risks and regulatory requirements, the closure objectives can be developed that form the basis for evaluating the closure options. Generally, the process of assessing closure options would typically include an evaluation of engineered-control measures to immobilise or isolate contaminants within a defined area or to reduce the flux of contaminants through a specific-exposure pathway. In the case of uranium tailings, the closure options typically need to address the risks associated with the potential for radionuclides to impair water resources and the exposure of receptors to elevated levels of ionising radiation and radon gas.

\section{Environmental considerations}

\subsection{Leaching of radionuclides}

\subsubsection{Oxidation reactions}

As is common practise for mine tailings generally, uranium tailings are conventionally stored in subaerial impoundments, where the tailings are directly exposed to atmospheric conditions. Consequently, exposure to atmospheric oxygen can result in the oxidation of the tailings material and the release of constituents into the dissolved phase. Depending on the mineralogical characteristics of the tailings, acidic pore waters with elevated concentrations of metals and radionuclides can be generated as a result of sulphide oxidation - commonly referred to as acid rock drainage. If sufficient neutralising minerals are present (i.e., carbonate minerals), near-neutral $\mathrm{pH}$ conditions will persist and the solubilisation of some constituents may be limited. However, it is important to note that the mobilisation of radionuclides, including the radioisotopes in the uranium-238 decay chain, can occur under near-neutral $\mathrm{pH}$ conditions.

Subaerial deposition of uranium tailings can result in the oxidation of the gangue and residual ore minerals, including uranium. For example, if the tailings are exposed to atmospheric conditions, uraninite can undergo the following oxidation-dissolution reaction (DeWindt et al., 2003):

$$
U O_{2_{(S)}}+\frac{1}{2} \mathrm{O}_{2_{(a q)}}+2 \mathrm{H}_{(a q)}^{+} \leftrightharpoons U \mathrm{O}_{(a q)}^{2+}+\mathrm{H}_{2} \mathrm{O}_{(a q)}
$$

As oxygenated pore water infiltrates down through the tailings, the concentrations of oxidised species (i.e., ferric iron, $\mathrm{Fe}^{3+}$ ) increases, which can in turn further oxidise or dissolve uraninite in the absence of dissolved oxygen:

$$
U O_{2_{(S)}}+2 \mathrm{Fe}_{(a q)}^{3+} \leftrightharpoons U \mathrm{O}_{2_{(a q)}^{2+}}^{2+}+2 \mathrm{Fe}_{(a q)}^{2+}
$$

Silicate minerals are also susceptible to weathering and dissolution processes. Thus, uranium-rich silicate minerals (e.g., uranothorite or uranophane) can also release uranium into the tailings pore water. In 
addition, uranium oxides and silicates commonly contain significant amounts of daughter products of uranium (i.e., thorium-230, radium-226) and thus can release additional radionuclides upon the dissolution of these mineral phases.

\subsubsection{Secondary mineral dissolution}

Uranium is commonly extracted from the ore using a strong acid leach to form a 'pregnant solution'. The tailings and process water (largely consisting of the 'raffinate' or 'barren solution') are separated from the pregnant solution and neutralised before deposition into the tailings management facility (TMF). The neutralisation process is conducted to ensure that alkaline conditions prevail. Drastically increasing the $\mathrm{pH}$ of the tailings by adding a neutralisation compound, such as lime, makes some dissolved constituents insoluble, resulting in the formation of secondary precipitates. As a result, secondary precipitates can make up a significant portion of the tailings solids. In the case of uranium tailings that have been processed using sulphuric acid and then subsequently neutralised, the calcium in the neutralising compound reacts with sulphate from the sulphuric acid to form secondary sulphate minerals (i.e., gypsum $\left[\mathrm{CaSO}_{4} \bullet 2 \mathrm{H}_{2} \mathrm{O}\right]$ ):

$$
\mathrm{Ca}_{(a q)}^{2+}+\mathrm{SO}_{4(a q)}^{2-}+2 \mathrm{H}_{2} \mathrm{O}_{(l)} \leftrightharpoons \mathrm{CaSO}_{4} \cdot 2 \mathrm{H}_{2} \mathrm{O}_{(s)}
$$

Neutralisation of tailings solids and process water can also result in the precipitation of secondary iron minerals. Widespread examples of secondary iron minerals in tailings include ferric oxyhydroxides (e.g., goethite $[\alpha \mathrm{FeO}(\mathrm{OH})])$ and ferric hydroxysulphates (e.g., jarosite $\left.\left[\mathrm{KFe}_{3}\left(\mathrm{SO}_{4}\right)_{2}(\mathrm{OH})_{6}\right]\right)(B$ lowes et al., 2004):

$$
\begin{gathered}
\mathrm{Fe}_{(a q)}^{3+}+2 \mathrm{H}_{2} \mathrm{O}_{(\mathrm{l})} \leftrightharpoons \alpha \mathrm{FeO}(\mathrm{OH})_{(s)}+3 \mathrm{H}_{(a q)}^{+} \\
\mathrm{K}_{(a q)}^{+}+3 \mathrm{Fe}_{(a q)}^{3+}+2 \mathrm{SO}_{4_{(a q)}}^{2-}+6 \mathrm{H}_{2} \mathrm{O}_{(l)} \leftrightharpoons \mathrm{KFe}_{3}\left(\mathrm{SO}_{4}\right)_{2}(\mathrm{OH})_{6_{(s)}}+6 \mathrm{H}_{(a q)}^{+}
\end{gathered}
$$

Co-precipitation with secondary minerals, such as sulphates, ferric oxyhydroxides and ferric hydroxysulphates, can be a significant sink for metals and radionuclides; this is particularly true for tailings that have been subjected to an acid leach process and then subsequently neutralised. Secondary minerals, however, can become unstable under changing geochemical conditions (i.e., changes in reductionoxidation potential, $\mathrm{pH}$ or concentrations of dissolved constituents); therefore, radionuclides may be released upon the dissolution of these secondary minerals. For example, as precipitation infiltrates into the subsurface and percolates down through the tailings, secondary minerals may dissolve, thereby releasing sequestered radionuclides. As a result, along with the oxidation of residual uranium minerals, the dissolution of secondary precipitates containing sequestered radionuclides is also a known, and in some cases a more important, mechanism that releases radionuclides into the tailings pore water. The mobilised radionuclides are then potentially available for transport into the downgradient groundwater and surface water environments. Because the mobilisation of radionuclides depends on geochemical conditions and the mineralogy of the tailings, the mechanism of release needs to be understood before the development of the closure strategies.

\section{$2.2 \quad$ lonising radiation}

Some elements, referred to as radionuclides or radioisotopes, undergo radioactive decay, whereby particles and photons are emitted from unstable nuclei. Generally, there are two types of radioactive decay: $\beta$-decay and $\alpha$-decay. The unstable nuclei is left in an excited state after the emission of the $\beta$ - or $\alpha$ particle; as such, the nucleus releases $\gamma$-rays to complete the decay process that forms a new element.

The release of ionising radiation from tailings is due to the decay of uranium and associated unstable daughter products. Uranium-238 has one of the longer natural decay chains, which results in a greater number of daughter products generating radioactivity. The release of ionising radiation from uranium tailings or from tailings that contain elevated concentrations of radionuclides can be at levels that result in radiation doses to receptors that exceed regulatory limits. Ultimately, the radiation dose depends on the type of radiation, the magnitude of the radioactive source and the exposure time. Closure strategies need to consider the risk to receptors that may be externally exposed to radiation and also to those receptors that may be internally exposed to radiation through inhalation or ingestion of radioactive materials. 


\subsection{Radon emissions}

A daughter product within the uranium-238 decay series is radon-222, which forms as a result of the decay of radium-226. Radon is a noble gas and does not readily bind chemically to other elements. As a result, as radon atoms are generated and released into the tailings pore space, the atoms are generally 'free' to diffuse through the unsaturated zone and ultimately be released into the atmosphere. Figure 1 shows a conceptual model of the release and transport of radon from the tailings surface.

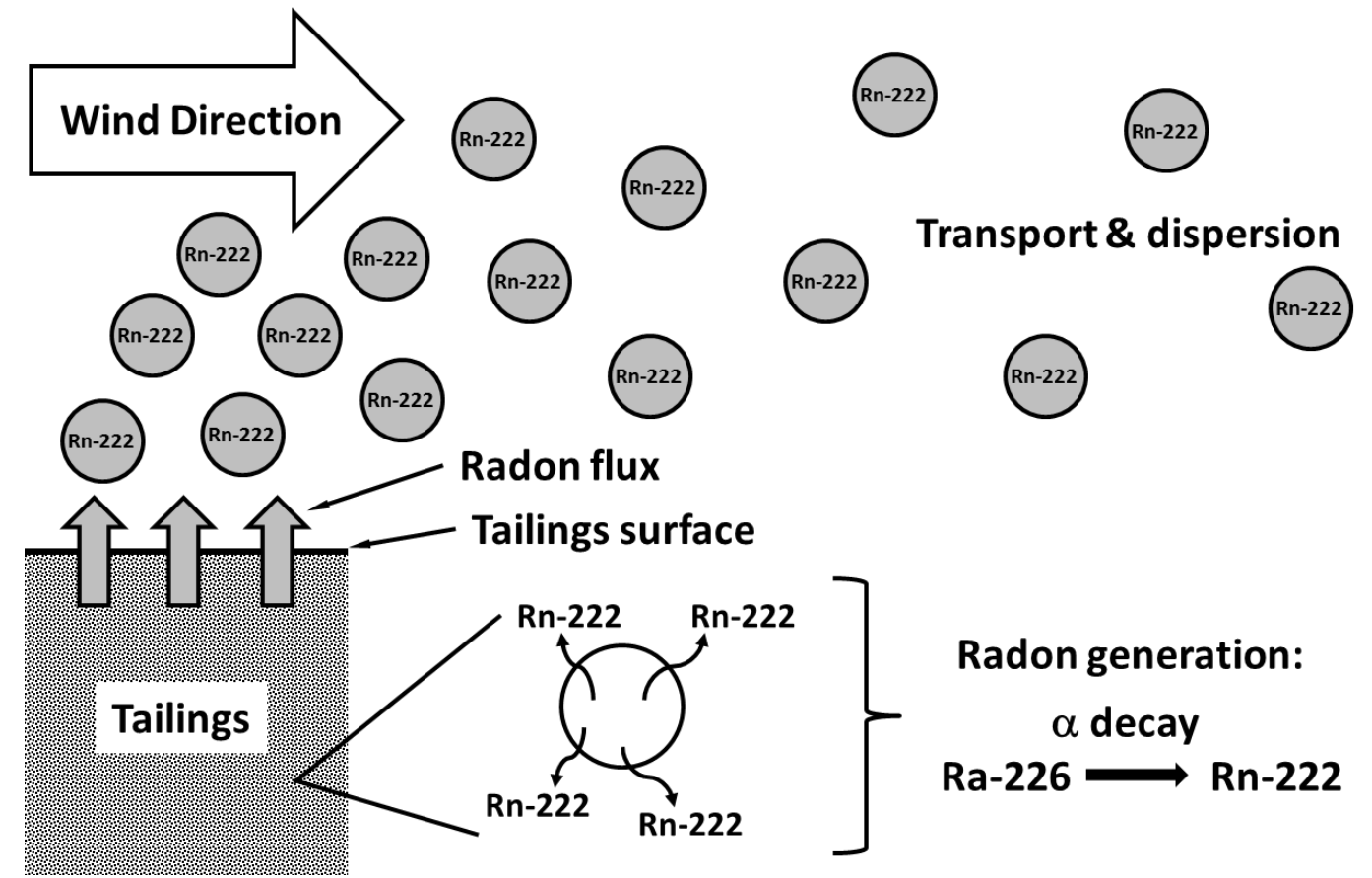

\section{Figure 1 Conceptual emanation of radon from uranium tailings}

Radon-222 has a half-life of 3.82 days, which can be sufficient time for the radon atoms to migrate up through the pore spaces of the unsaturated tailings zone and enter the surface environment. Given the half-life and an inability to chemically bind to other materials, radon can travel significant distances under the right climatic conditions.

The rate of transport of gaseous radon through unsaturated porous media, and therefore the rate of radon flux from the ground surface, is influenced by several factors, including grain size, porosity, conductivity, degree of water saturation, pore pressures and radon concentration gradients. The effective diffusion length is primarily a function of soil permeability, which in turn is a function of soil porosity and pore space connectivity. Once radon has migrated to the surface it will disperse through the air column and migrate via solar heating and wind currents. The radon diffusion coefficient in water is significantly lower than the diffusion coefficient in air; therefore, radon diffusion in the subsurface decreases significantly with increasing moisture saturation (Rogers et al., 1984). As such, strategies to mitigate the release of radon gas are commonly based on maintaining saturated or near-saturated conditions to reduce the diffusion rate of radon through the tailings pore space network. If maintaining saturated conditions is not possible, some radon mitigation strategies have been focused on increasing the radon diffusion pathway length - the basis being that, before reaching the surface, the radon decays into its daughter products along the transport pathways. Unlike radon gas, the radon progeny are chemically active and will adhere to soil particles below the surface of the tailings (Rogers et al., 1984).

\section{Radiation protection regulatory framework}

Consideration of local environmental and mine closure regulations and legislation is generally accepted as standard practice when developing closure strategies for mine sites, including tailings management 
facilities. However, given the presence of radioactive materials, radiation protection regulations require special consideration when formulating an approach for closing uranium tailings facilities. The International Atomic Energy Association (IAEA) establishes standards of safety for the protection of health, life and property in the development of nuclear energy. Radioactive mine waste safety guidelines have been developed by the IAEA and are published in Management of Radioactive Waste from the Mining and Milling of Ores (IAEA, 2002). The IAEA guidelines indicate that the public radiation dose limit should not exceed $1 \mathrm{mSv} /$ year and that mine closure strategies should minimise the need for institutional controls postclosure.

In Canada, uranium mine and mill sites are regulated under the Nuclear Safety and Control Act (NSCA), as the production, possession and use of nuclear energy or nuclear substances are regulated by the NSCA. Because uranium tailings are low-level radioactive wastes that were produced while the site was operating as a 'nuclear facility', the tailings management facilities are subject to licensing by the Canadian Nuclear Safety Commission under the terms of the Nuclear Substances and Radiation Devices Regulations. Under the Canadian regulations, a maximum annual dose limit of $1 \mathrm{mSv} / \mathrm{year}$ is specified for members of the public; however, the regulatory guidance also references the ALARA approach (an abbreviation for As Low As Reasonably Achievable). In some cases, the regulatory expectation will be to achieve annual doses less than $1 \mathrm{mSv} /$ year, based on the ALARA approach.

In the USA, regulations pertaining to the disposal of uranium mine tailings are outlined in the Code of Federal Regulations (10 CFR Part 40) and administered by the United States Nuclear Regulatory Commission. The US regulations specify that uranium tailings are to be covered over with a soil cover (or an approved alternative) that is to be effective for 1,000 years, or to the extent reasonably achieved, and for a minimum of 200 years. Closure strategies for uranium tailings facilities in the USA need to be designed such that the average flux rate of radon to the atmosphere is less than $20 \mathrm{pCi} / \mathrm{m}^{2} / \mathrm{s}\left(0.74 \mathrm{~Bq} / \mathrm{m}^{2} / \mathrm{s}\right)$ and the maximum public dose limit is $100 \mathrm{mrem} /$ year (1 mSv/year).

In Western Australia, the Department of Consumer and Employment Protection has issued a series of Naturally Occurring Radioactive Material guidelines. These deal with the management of radioactive waste and specify an annual dose limit between 0 and $0.3 \mathrm{mSv} / \mathrm{year}$ for sites with unrestricted access and an annual dose limit between 0.3 to $1.0 \mathrm{mSv} /$ year for sites with restricted access.

In the UK, the Health and Safety Executive provides regulation pertaining to acceptable radiation dose and control measures. The UK lonising Radiations Regulations state that for all other persons (non-employees of an employer) the maximum radiation dose shall not exceed $1 \mathrm{mSv}$ in any calendar year.

\section{$4 \quad$ Uranium tailings closure and rehabilitation strategies}

The closure and rehabilitation strategies discussed in this section provide conceptual-level detail on some technologies that are available to mitigate the risks associated with uranium tailings. Discussion on closure and rehabilitation strategies herein is limited to those that focus on reducing radionuclide loading to groundwater, reducing the radon flux emitted from the tailings, minimising the level of ionising radiation at the surface and/or preventing migration of radioactive material from the site. Furthermore, the discussion on closure strategies is focussed on passive technologies, with only a brief mention regarding active treatment. Although the use of active treatment technologies may be required at some sites (i.e., pump and treat, soil vapour extraction), minimising the need for perpetual maintenance and caretaking are generally considered to be key closure objectives.

The applicability and effectiveness of particular closure/rehabilitation strategies will vary from site to site, due to differing physical, climatic and geochemical conditions and also due to the nuances of local regulations. A preliminary options screening study followed by a detailed alternatives assessment are typical steps in the process of evaluating and selecting closure/rehabilitation options that are both practical and feasible. The conceptual options presented here may be included as part of a preliminary options screening process for uranium tailings, with the preferred option, or a combination of preferred options, being selected based on the fulfilment of the project-specific closure objectives. 


\subsection{Water cover}

Water covers are an effective way to reduce the radon flux emitted from tailings due to the low diffusion rate of radon through water $\left(\sim 10^{-5} \mathrm{~cm} / \mathrm{s}\right)$ compared with air $\left(\sim 10^{-1} \mathrm{~cm} / \mathrm{s}\right)$ (Nazaroff, 1992). Figure 2 provides a schematic cross-section of a water cover. Operating the tailings facility under a flooded state would maintain fully saturated conditions throughout the tailings and would significantly reduce the rate at which radon was transported from depth to surface (compared with unsaturated or partly saturated conditions). If the tailings are fully saturated, and conservatively assuming radon diffuses through saturated tailings at the same speed as pure water, the concentration of radon would theoretically decrease by a factor of about $0.5 \times 10^{29}$ for every $1 \mathrm{~m}$ of distance travelled. The water cover also provides a physical barrier between the tailings and surface environment. Assuming the water cover is perpetually sustainable, it would prevent wind erosion of the tailings beach and therefore prevent migration of radioactive dust to receptors.

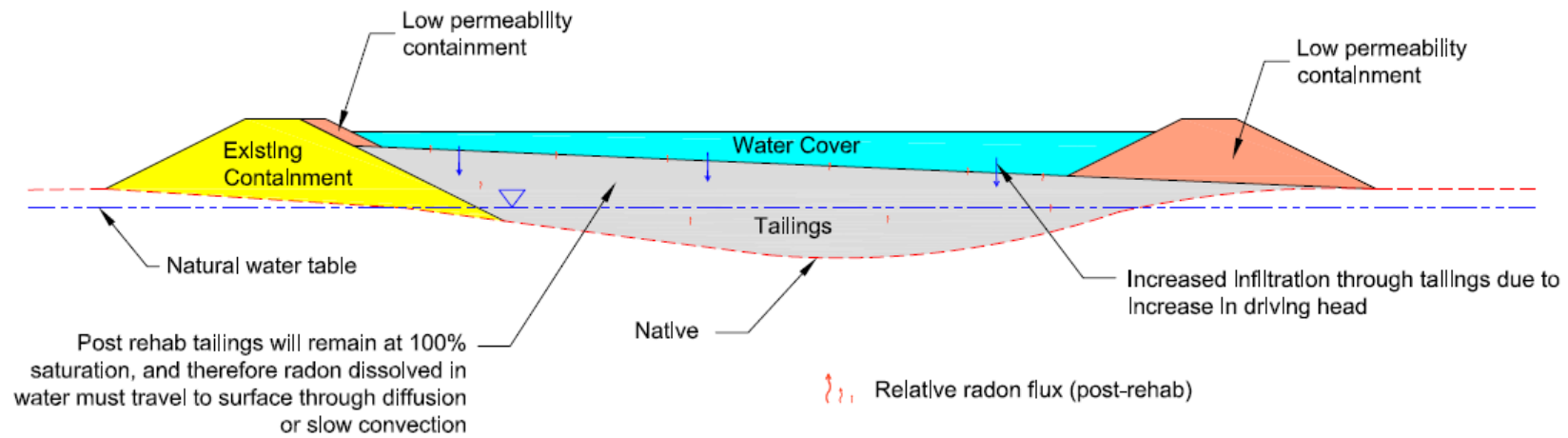

\section{Figure 2 Schematic cross-section of a water cover}

Implementation of a water cover can give rise to issues regarding radionuclide loading to groundwater. The increase in hydraulic head that results from the water cover would increase the hydraulic gradient and therefore increase the rate at which radionuclide-bearing groundwater flows through the tailings and into the adjacent groundwater flow regime. However, if the potential groundwater impacts are evaluated during the initial stages of closure planning, the tailings facility design could incorporate complete lowpermeability containment and, if required, a leak detection/collection system to control impacts to groundwater.

The use of a water cover for closure requires planning early on in the project development. The designer must ensure that the climatic conditions and upstream catchment are sufficient to recharge the cover. In addition, containment of the water cover is required to limit the rate of groundwater seepage, which is of particular importance if the tailings leachate contains elevated concentrations of metals and radionuclides. The tailings facility must be designed with an outlet structure to pass the design storm event without overtopping of the dam. Operation of a water cover over tailings impounded behind a dam has inherent risk associated with overtopping of the dams and the subsequent potential for dam failure and complete loss of tailings containment. Furthermore, with the ever-growing uncertainty with respect to the possibility of climate change, the long-term sustainability of a water cover as a tailings closure option becomes increasingly difficult to justify.

\subsection{Dry capping - soil cover}

The most common method used for closure of uranium tailings facilities is the placement of a dry soil cover (i.e., capping of the facility), and in countries such as the USA special approval is required to close out uranium tailings with options other than a soil cover (US NRC, 2013). Soil covers are advantageous due to their flexibility and ability to be designed to satisfy a wide range of design criteria. From a uranium tailings management perspective, soil covers are often the go-to choice because covers can be designed to address a combination of issues, including radon emissions, release of ionising radiation, radionuclide loading to site drainage and physical stability (reducing erosion and dusting). Soil covers are also flexible in the sense that 
a single design criterion could be satisfied by a multitude of soil cover configurations. A typical soil cover cross-section is provided in Figure 3.

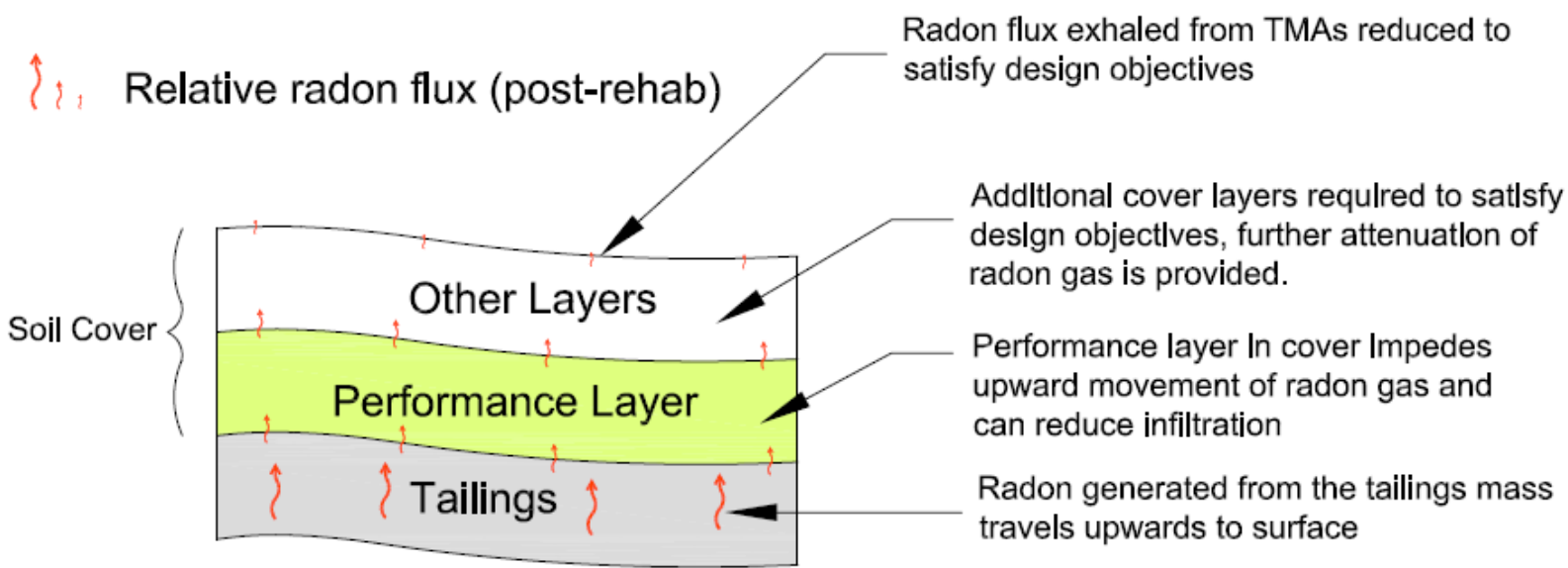

\section{Figure 3 Simplified soil cover profile}

Properties of a soil cover can be modified with relative ease, allowing the design to be tailored to address site-specific requirements. Reduction of radionuclide loading to groundwater and surface water can be addressed by reducing infiltration into the tailings, which can be accomplished through the inclusion of a low-permeability layer in the soil cover. Depending on the availability of construction materials, this lowpermeability layer may be a natural soil, such as till or clay. Incorporating positive drainage in the final landform design of the soil cover would also have beneficial effects on reducing infiltration into the underlying tailings.

Placement of a soil cover of any thickness over the tailings provides an additional network of pore space that radon gas emanating from the tailings must travel through prior to atmospheric release. The increased tortuosity of the pore space network provides increased opportunity for radon gas to undergo radioactive decay prior to exiting the surface of the tailings. Considering a completely unsaturated soil cover, a homogenous soil cover of sufficient thickness may sufficiently impede radon gas movement and reduce the radon flux emitted from the tailings to acceptable levels. Further reductions in the radon flux are possible through the inclusion of saturated fine-grain layers within the soil cover, or layers with low gas permeability, thereby decreasing the effective diffusion rate of radon through the soil cover. Emplacement of a soil cover that contains a layer designed to retain a high degree of saturation can also be used to limit the ingress of oxygen, thereby reducing the rate of mineral oxidation (e.g., sulphide- or radionuclidebearing minerals) and the mobilisation of metals and radionuclides.

The soil cover acts as a physical barrier that separates the tailings from the surface environment. The cover thickness provides shielding from ionising radiation, and it prevents erosive forces from transporting radioactive particles to downstream receptors. The requirement to provide shielding from ionising radiation, and the target dose levels, will ultimately be a function of the end land use of the TMF.

\subsection{Synthetic covers and in situ stabilisation}

Synthetic covers or in situ stabilisation are alternate approaches to the more conventional soil cover. Soil stabilisation relies on chemical reactions or mechanical bonds to create a stable soil-contaminant structure. The migration of radon gas emanating from the tailings would be slowed by the monolithic solidified soil mass, significantly reducing the diffusion rate compared with virgin tailings. Figure 4 provides a schematic cross-section of in situ stabilisation of a tailings beach. 


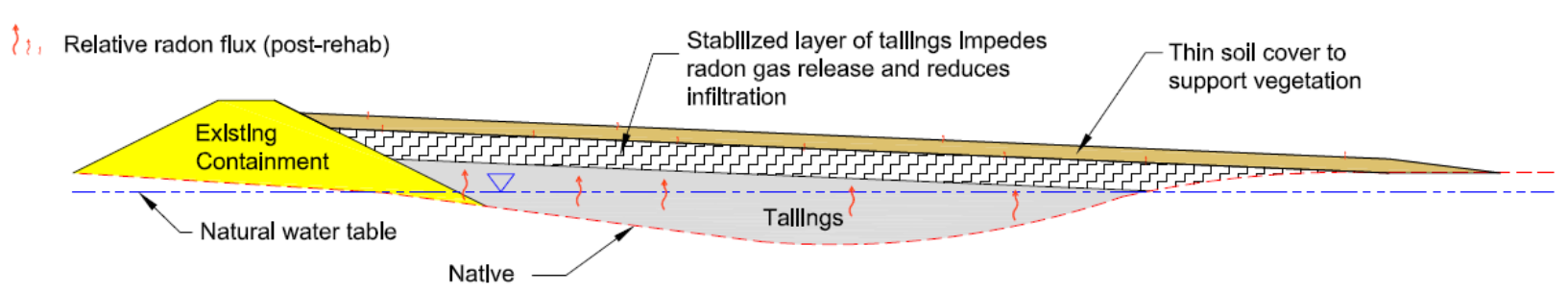

\section{Figure 4 Schematic cross-section of in situ stabilisation of tailings}

There are several methods available to stabilise the mass of contaminated materials, which include in-situ soil vitrification (Pacific Northwest Laboratory, 1984), cementation or binding with bitumen/asphalt. Polyethylene encapsulation of the tailings has also shown to be effective at immobilising contaminants (Construction Industry Research and Information Association, 2004). The effectiveness of a specific stabilisation method will be largely dependent on the site-specific tailings properties.

Stabilisation of the surficial tailings can also significantly reduce the tailings' permeability, reducing infiltration into the tailings and the radionuclide loading of groundwater. The permeability of the stabilised tailings mass would be dependent on the method of stabilisation used and the depth of stabilisation selected based on the infiltration reduction required to meet groundwater quality targets.

Stabilisation of the surficial tailings would reduce the amount of dust generated from wind erosion compared with virgin tailings, therefore reducing the potential for migration of radioactive dust from the site. Placement of topsoil and vegetation of the stabilised tailings would provide further protection against erosion and migration of radioactive dust from the site and improve its overall aesthetics.

Use of a synthetic cover at closure would be implemented as per Figure 3, where the 'performance layer' of the cover would consist of a geosynthetic material. A wide range of geosynthetics are available that would offer similar performance in terms of reducing radon flux emitted from, and infiltration into, the TMF. Some examples of suitable geosynthetic materials include high- and low-density polyethylene liners (HDPE and LLDPE), bitumous geomembrane liners, geosynthetic clay liners and asphalt. Each of these geosynthetic materials has specific strengths and weaknesses with regard to gas permeability, ease of installation, construction flexibility and long-term performance. However, given that mine closure is for perpetuity, obtaining regulatory approval for the use of geosynthetics as the performance layer in a closure application may be difficult. Current manufacturer claims typically only warranty products such as HDPE and LLDPE for around 25 years; this is a relatively short period of time considering that a closed-out TMF will be in existence for perpetuity.

\subsection{Active and passive water treatment systems}

Active treatment systems are those that require ongoing operation, maintenance and monitoring and are widely employed at mine sites to treat drainage from mine wastes, including tailings. Collection and treatment, often referred to as 'pump and treat', is used to capture the drainage in ditches and ponds, which is then conveyed to a treatment facility. The effluent can then be treated using a variety of technologies, depending on the water chemistry and contaminants of concern, including neutralisation (i.e., pH adjustment), chemical precipitation, aeration, membrane processes, ion exchange and microbiological removal.

Passive technologies or systems for the treatment of groundwater or surface water include those that do not require 'active' caretaking and maintenance. Constructed wetlands, bioreactors and permeable reactive barriers are examples of passive treatment systems that have been used for the remediation of mine site drainage and can be applied to drainage at uranium mine sites (Blowes et al., 2004; Construction Industry Research and Information Association, 2004; Fuller et al., 2002; Naftz et al., 2002; US EPA, 2000).

Passive treatment systems can use the following mechanisms or a combination of them to treat water and reduce the concentrations of the contaminants of concern: abiotic/biotic reduction, chemical precipitation, 
adsorption, ion exchange and plant uptake. Although passive treatment technologies can be effective in improving the quality of groundwater and surface water, these are typically constructed downgradient or downstream of the source zone and do not mitigate further release of contaminants. As such, passive treatment options are often coupled with other closure options that target the source term, which for uranium tailings facilities may need to consider mitigating the release of radon gas in addition to generating degraded groundwater seepage and surface runoff.

\section{$5 \quad$ Conclusions}

Uranium tailings are low-level radioactive wastes that require special management and closure considerations. Environmental issues that can be associated with uranium tailings, and less commonly related to other mine types, include groundwater and surface water contamination by radionuclides, emanation of ionising radiation and air pollution due to the release of radon gas. Before evaluating potential closure or rehabilitation strategies for uranium tailings facilities, the technical aspects and the risks related to these environmental issues need to be well understood. As such, the potential sources, pathways and receptors of radiation and radioactive substances require special consideration as part of the closure planning process. Furthermore, local governing policies, acts and regulations will be key drivers in formulating the closure or rehabilitation framework, in particular the relevant radiation protection standards and guidelines.

Closure strategies for uranium tailings may include the implementation of a combination of engineeredcontrol measures to eliminate the contaminant source, immobilise or isolate contaminants within a defined area or reduce the flux of contaminants through a specific-exposure pathway. Some examples of conceptual closure options that may be included in a preliminary conceptual options screening process include water covers, soil covers, in situ stabilisation and active and/or passive water treatment. Ultimately, the selected strategy will likely consist of a combination of technologies that best fit the site-specific conditions, the local regulatory environment and the overall site closure objectives.

\section{References}

Blowes, D.W., Ptacek, C.J., Jambor, J.L. and Weisner, C.G. (2004) The geochemistry of mine drainage, in B.S. Lollar, H.D. Holland and K.K. Turekian (eds), Treatise on Geochemistry, Environmental Geochemistry, Vol. 9, pp. 149-204.

Bryan, C.R. and Siegel, M.D. (2004) Environmental geochemistry of radioactive contamination, in B.S. Lollar, H.D. Holland and K.K. Turekian (eds), Treatise on Geochemistry, Environmental Geochemistry, Vol. 9, pp. 205-262.

Construction Industry Research and Information Association (2004) Safegrounds - Technical Options for Managing Contaminated Land, H. Mallet (ed), Classic House, London.

DeWindt, L., Burnol, A., Montarnal, P. and Van der Lee, J. (2003) Intercomparison of reactive transport models applied to UO2 oxidative dissolution and uranium migration, Journal of Contaminant Hydrology, Vol. 61, p. 303.

Fuller, C.C., Piana, M.J., Bargar, J.R., Davis, J.A. and Kohler, M. (2002) Evaluation of apatite materials for use in permeable reactive barriers for the remediation of uranium-contaminated groundwater, in Handbook of Groundwater Remediation Using Permeable Reactive Barriers-Applications to Radionuclides, Trace Metals, and Nutrients, D.L. Naftz, S.J. Morrison, J.A. Davis and C.C. Fuller (eds), Academic Press, San Diego, CA, pp. 255-280.

IAEA (International Atomic Energy Agency) (2002) Management of Radioactive Waste from the Mining and Milling of Ores, Vienna. Nazaroff, W.W. (1992) Radon transport from soil to air, Review of Geophysics, Vol. 30(2), pp. 137-160.

Naftz, D.L., Fuller, C.C., Davis, J.A., Morrison, S.J., Feltcorn, E.M., Freethey, G.W., Rowland, R.C., Wilkowske, C. and Piana, M. (2002) Field demonstration of three permeable reactive barriers to control uranium contamination in groundwater, Fry Canyon, Utah, in Handbook of Groundwater Remediation Using Permeable Reactive Barriers-Applications to Radionuclides, Trace Metals, and Nutrients, D.L. Naftz, S.J. Morrison, J.A. Davis and C.C. Fuller (eds), Academic Press, San Diego, CA, pp. 401-434.

Pacific Northwest Laboratory (1984) An In Situ Vitrification Pilot - Scale Radioactive Test, C.L. Timmerman and K.H. Oma (eds), Washington.

Rogers, V.C., Nielson, K.K. and Kalwarf, D.R. (1984) Radon Attenuation Handbook for Uranium Mill Tailings Cover Design, prepared for U.S. Nuclear Regulatory Commission.

US NRC (Nuclear Regulatory Commission) (2013) Appendix A to Part 40-Criteria Relating to the Operation of Uranium Mills and the Disposition of Tailings or Wastes Produced by the Extraction or Concentration of Source Material From Ores Processed Primarily for Their Source Material Content, viewed 1 May 2013, http://www.nrc.gov/reading-rm/doccollections/cfr/part040/part040-appa.html.

US EPA (2000) Environmental Protection Agency. Field Demonstration of Permeable Reactive Barriers to Remove Dissolved Uranium from Groundwater, Fry Canyon, Utah, Washington. 
